\title{
THE JURY SYSTEM IN DEATH PENALTY CASES: A SYMBOLIC GESTURE
}

\section{Courtney Mullin*}

"The death penalty is . . a privilege of the poor," said Clinton Duffy, former warden of the infamous San Quenton Prison and executioner of 90 persons. ${ }^{1}$ Since death as punishment was legalized again in $1976,{ }^{2}$ as a society we have selected more than 551 persons for execution. ${ }^{3}$

Out of the thousands of persons who commit homocide each year, only a symbolic few are selected by prosecutors for the death penalty. ${ }^{4}$ The public assumes that standards have been established to assure fairness in determining which cases meet specific requirements for exposure to this penalty. This is not the case. Initially, only the subjective judgment of prosecutors determines who faces death as punishment.

Joe Hooper, former warden of the Georgia State Prison, pointed out during a 1978 interview with the author that the brutality of the murder is not the most important variable in determining who receives the death penalty.

\footnotetext{
* Consulting Juristic Psychologist, Raleigh, N.C.

1. J. Breig, Does Killing Criminals Stop Crime?, U.S. Catr., May 1978, at 27.

2. Gregg v. Georgia, 428 U.S. 153 (1976); Proffitt v. Florida, 428 U.S. 242 (1976); Jurek v. Texas, 428 U.S. 262 (1976).

3. This figure is accurate as of September 1, 1979, according to Patsy Morris, Director of the ACLU Death Penalty Project, Atlanta, Georgia. Also, of the fifty states, thirty-six have instituted death penalty statutes, including generally liberal states such as Oregon. See Or. Rev. Stat. § 163.115 .

4. According to a statement made by Fred Wilkinson, former warden of the U.S Penitentiary in Atlanta on October 8, 1959, "It is a provable fact that no more than one percent of offenders who are eligible for execution by reason of their offenses . . . are ever put to death." The statement was entitled "I Am Opposed to Capital Punishment" and appears in The Church Speaks: Capital Punishment (The booklet is available from the Materials Distribution Service, Presbyterian Church in the U.S., 341 Fonce de Leon Ave., Atlanta, Ga. This booklet does not have numbered pages, but the statement appears under the topic heading, Inequity in Application). In North Carolina only 35 percent of whites sentenced to death were finally executed, while the comparable figure for blacks was 67 percent. M. Wolfgang \& B. Cohen, Crime and Race: ConCEPTIONS AND Misconceptions 85-86 (1970).

Even though nearly three quarters of all homocides involve family members, friends or acquaintances (according to the 1974 FBI Crime Reports), it is extremely rare for a prosecutor to seek the death penalty for such "crimes of passion." Furthermore, officers of companies such as the Firestone Corporation, who with malice and premeditation have killed and maimed hundreds of persons by knowingly placing defective merchandise on the market, have not been subjected to the threat of the death penalty.
} 


\section{THE STATE}

VS.

\section{SAMUEL GIBSON, III.}

NO. \# $\underline{3835}$

INDICTMENT FOR Murder IN THE SUPERIOR $\overline{\text { COURT OF }}$ JONES COUNTY, GEORGIA

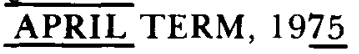

The defendant, Samuel Gibson, III, on the trial of the above stated case, at the April Term, 1975, of this Court, having been convicted of the charge and crime of Murder, and defendant now being before the bar of this Court, and showing no cause why the sentence of the Court should not be pronounced:

IT IS CONSIDERED, ORDERED AND ADJUDGED BY THE COURT That you, Samuel Gibson, III, be taken from the bar of this Court, where you now stand, to the common jail of Jones County, Georgia, where you shall be safely kept and confined until you shall be removed therefrom by the official and in the manner provided by law, and under the terms and conditions specified by law, when you shall be delivered to the Director of Corrections of the State of Georgia, for electrocution at such penal institution as may be designated by said Board. In such institution, you shall be submitted to the penalty of death by electrocution, as provided by law between the hours of ten o'clock in the forenoon and two o'clock in the afternoon on the 4th day of June, 1980. $\neq$ And, may the Lord have Mercy on your soul.

IT IS FURTHER ORDERED, That said execution be done by the Warden of the said State Penitentiary, or a deputy warden thereof, who shall serve as executioner, together with at least two assistants, in the presence of two physicians, to determine when death supervenes, and an electrician, a suitable guard, and if you so desire, your counsel, relatives, and such clergymen and friends as you may desire to have present.

So pronounced and ordered by the Court, in Open Court, this the 16th day of May, 1980.

$\frac{\text { [Joseph H. Briley] }}{\text { District Attorney }}$

$\frac{\text { [George L. Jackson] }}{\text { Judge, Superior Courts }}$

Ocmulgee Judicial Circuit

FILED IN OFFICE THIS [16th] DAY

OF $\underline{\text { [MAY] }} 19 \underline{[80]}$

$\frac{\text { [W.J. Roberts] }}{\text { CLERK }}$

$\ddagger$ Gibson's case is currently on appeal. 
Warden Hooper remarked that, in his experience, perpetrators of some of the most heinous crimes have received life in prison as punishment, while people convicted of "routine" killings have received the death penalty.

For a so-called "crime of passion," John Spenkelink was executed by the state of Florida in May 1979. Although Spenkelink was offered a plea bargain to second degree murder for the killing of his homosexual lover, he chose to go to trial and ultimately received the death penalty. ${ }^{5}$ Ironically, had Spenkelink accepted the plea bargain, he would have been eligible for parole at approximately the same time he was executed.

It appears that social variables determine which persons will be singled out to receive the death penalty. ${ }^{6}$ Death row inmates represent a cognizable class of persons. Not only are they poor, they are young, male, and often a member of a minority group. These persons generally reside in the rural South, the nation's death belt, and have murdered a person of high status. In almost every instance, the murder victim is white. ${ }^{7}$

The legal defense provided for these "execution prone" persons is adequate at best, but usually poor. ${ }^{8}$ It is not uncommon for a man to receive the death penalty in a one day trial. Spenkelink's lawyer left the courtroom for a number of hours during the course of his trial. ${ }^{9}$ A Georgia death row inmate had a lawyer who went to sleep during the course of the murder trial. ${ }^{10}$

In the widely publicized Florida coed murders, Theodore Bundy ${ }^{11}$ was

5. Millard Farmer, with Margie Pitts Hames and Ramsey Clark, represented Spenkelink as his third set of lawyers. Farmer reports that Spenkelink was convinced that he would be found not guilty in his trial and so refused the plea bargain. Unfortunately it is not uncommon for clients to refuse to take the advice of their attorneys and accept a plea bargain. After discussions with many attorneys who have faced this problem, I have concluded that often so little rapport and trust exist in the attorney-client relationship that clients follow the advice of family, friends or other inmates rather than the realistic advice of their lawyer.

6. For an excellent overview see W. Bowers, Executions in America 18-19, 71-102 (1974); see also M. Riedel, The Poor and Capital Punishment, 45 Prison J. 24 (1965).

7. Bowers, supra note 6, at 31-109.

8. See Ferri v. Ackerman, 48 U.S.L.W. 4054 (December 4, 1979). Chief Justice Burger has said that one-half of all U.S. trial lawyers are unqualified to represent their clients, see R. Carelli, No Verdict Reached on the Fitness of Lawyers, News and Observer, Raleigh, N.C., October 29, 1978 , at $4, \S \mathrm{VI}$, col. 1 .

9. The handling of death penalty cases is considered a speciality within the law in much the same way that brain surgery differs from the general practice in medicine. As a result, most death penalty cases are incompetently handled. The issue of incompetency remains a touchy one for many attorneys. In appealing John Spenkelink's case, his second set of attorneys failed to demonstrate that his first attorney had stated on the record that he felt unable to handle a trial of such magnitude, that he was physically absent from the courtroom for a period of time during the trial of the case, and that he had not prepared his client to testify-the end result being Spenkelink testifying to the jury on the issue of sodomy using jailhouse slang to describe these acts. This crucial issue was raised by Spenklink's final team of attorneys only hours before he was to be executed.

10. Fleming v. State, 243 Ga. 120, 252 S.E.2d 609 (1979).

11. For actual transcripts and briefs filed in this and other cases by death penalty specialists, see Fighting Oppression in the Courts (Team Defense Projects, Inc., Atlanta, Ga, 1978). 
denied the right to be represented by death penalty trial specialist Millard Farmer and was ultimately represented by a Florida public defender who had never tried a criminal case. This attorney was a recent law school graduate whose legal experience had been confined to writing appellate briefs.

In no other type of trial does emotionality and prejudice so control the verdict. A unique set of interrelating variables operate in the death penalty trial which, if carefully assessed, make it possible to determine which cases will lead to execution. These variables include the facts that the defendant is execution prone, that massive publicity has occurred, that the community is outraged by the crime and is convinced that the defendant is guilty, and that tremendous public pressure is placed on the judge, the prosecutor, the defense attorney and the jury. ${ }^{12}$ Furthermore, the jury selection process is unfairly biased against the defendant in that the jury pool does not represent a cross section of the community, the death qualification of potential jurors results in a more prosecution-prone jury, and the voir dire is limited to the point that individual prejudices and opinions held by potential jurors are impossible to detect. ${ }^{13}$

The "execution" trial evolves from an ordinary case, in which jurors simply determine whether one person has killed another, into an emotional event in which societal pressures are so intense that the traditional safeguards of legal theory insuring a defendant a fair and impartial trial are rendered useless.

12. In death penalty cases, the jurors are instructed that they must find at least one aggravating circumstance before imposing the death penalty. However, they are also instructed that it is possible for them to find aggravating circumstances and still impose a life sentence. Many, though not all, judges charge the jury that the prosecutor carrier the burden of proving the existence of aggravating circumstances and that such circumstances must be proven beyond a reasonable doubt. Most specialists in death penalty cases argue that jurors should be instructed to presume a life sentence at the outset of the penalty phase of the trial, the burden of proving aggravating circumstances beyond a reasonable doubt rests soley on the prosecutor. Furthermore, the jury should be instructed that the defendant is not required to offer any evidence whatever in mitigation. See also A. Scheflin \& J. Van Dyke, Jury Nullification: the Contours of a Controversy, 43:4 Law \& Contemp. Prob., Autumn 1980, at 51.

13. To be eligible to serve in death penalty cases, jurors must declare under oath that they are able to consider the sentence of death as a possible verdict in the case should it go to the second phase of the trial. This process is termed death qualifying of jurors, a somewhat gruesome but apt phrase, in that each juror must swear that he or she will consider executing another human being. This process results in the exclusion of a cognizable class of persons from the jury: those who are conscientiously opposed to the death penalty. Social science research has found that a death qualified jury is more likely to vote guilty than a non-death qualified jury when presented with an identical fact situation. Thus, the chances of a defendant in a death penalty case being found guilty are heightened when he or she faces a death qualified jury.

A number of attorneys have attempted to remedy this situation by moving for separate trial juries to be selected for the two trial phases or for proceeding with fewer than twelve jurors should the second trial phase become necessary. This has not yet, to my knowledge, been allowed by trial judges.

For more details of these problems, see Fighting Oppression in the Courts, supra note 11 , and B. Bonora \& Krauss, Jurywork: Systematic Techniques (1979) [hereinafter cited as JURYWORK]. 
In execution cases, it is highly probable that the defendant will be sentenced to death even when he is represented by skillful counsel who specialize in death penalty cases. ${ }^{14}$

When a high status white person is murdered by a poor, young black male in the rural South, the community undergoes a predictable emotional change. The murder escalates into a symbolic threat to the existing status quo of the community, and community members seem to feel that the predictability of their lives has been disrupted. The murder precipitates a feeling of outrage and horror that spreads throughout the community; people begin to desire vengeance against the perpetrator of this psychological turmoil. ${ }^{15}$

This feeling was expressed by a female resident of a small, south Georgia town. When asked to comment on the guilt or innocence of a poor, black male who was accused of murdering the town's police chief, she responded that she was sure the accused was guilty but she hoped he would go free. When asked why she felt this way, she answered: "Because he'd be dead before he reached the county line." 16

Execution cases are widely followed and discussed within a community. It is not uncommon to find that more than 90 percent of the respondents to public opinion polls conducted on behalf of defendants in these cases have heard of the case. An analysis of poll results reveals a remarkable degree of homogeneity of attitudinal patterns found within these communities, especially in regard to authoritarianism. Often there is community-wide consensus that the defendant is guilty. Pre- and post-trial interviews of community members reveal that the decision concerning the guilt of the accused begins with the act of murder, is followed by a sense of outrage and intensive communitywide discussions as people seek to understand why this terrible act has occurred, and finally culminates with a decision that the accused is guilty and a feeling that the restoration of order in their lives will be accomplished only when the accused receives "justice." 17 It would be naive to expect court

14. Law Enforcement Assistance Administration, U.S. Dep't of Justice, Capital PunishMENT 1977, at 12, 16 (1978) (the Spenkelink execution is not included in this figure). Defendants will henceforth be termed "he." According to the National Prisoner Statistics, only 32 women have been executed since 1930 , compared to 3,828 males executed.

15. In a concurring opinion in Nebraska Press Association v. Stuart, 427 U.S. 539,600 n.22 (1976), Justice Brennan argued: "[T]he smaller the community, the more likely there will be a need for a change of venue in any event when a heinous crime is committed."

16. This poll was conducted by the Team Defense Project, Inc., of Atlanta, Georgia in 1977. This group (comprised of attorneys, social scientists and legal workers), specializing in the defense of death penalty cases, conducted the poll in an effort to obtain data concerning community attitudes as evidence to present to the court during the change of venue motion. The motion was ultimately granted.

17. During the course of five year's work in this area, I have conducted thousands of surveys of jurors and potential jurors. The methodology has included almost every standard approach: telephone, face-to-face, close-ended questions, open-ended questions and various combinations of these approaches. Data analysis was conducted via conventional methodologies including 
officials to remain immune to this process. In fact, the role of the judge and the prosecutor as guardian of community standards becomes more symbolic than real in execution cases.

For example, it would seem likely that in execution cases, in which intense publicity has resulted in a large percentage of the populace having formed an opinion as to the guilt of the accused, in the interest of justice, the judge would grant a change of venue. The U.S. Supreme Court has ruled that a change of venue may be granted whenever prejudice is a "reasonable likelihood"18 or a "probability." These cases represent "a departure from the traditional view that . . . actual prejudice, not simply the likelihood of harm, must be shown in order to obtain relief."19

In practice, judges in execution cases seldom grant the change of venue motion. They simply respond to the community pressure. The community demands justice and exerts tremendous pressure on the judge to keep the murder trial within its sphere of influence. As a practical matter, judges (particularly those elected from small rural areas) risk their jobs if they offend their constituents by changing the trial location. Since the change of venue is discretionary with the judge, is costly in terms of time and money, and is not customarily granted, most judges opt to deny the motion even though they may recognize that their decision increases the probability of conviction.

Prosecutors are also affected by the awesome pressure from the community. Once a case has evolved into an execution case, a prosecutor is usually unable to plea bargain with the defendant and is pressured to bring the case to trial as rapidly as possible.

Frustrated after ten months of unsuccessful efforts to bring the execution case of Henry Willis ${ }^{20}$ to trial, south Georgia prosecutor Vickers Nugent burned a law book in front of the Lanier County Courthouse. He declared to the assembled press that if he could not get a judge to try the case, he no longer had any need for his law books. ${ }^{21}$.

It is interesting to note that nine judges excused themselves from this case for cause. After twenty-four months and a change of venue, the case was brought to trial. Four defense attorneys assisted by a team of juror selection

\footnotetext{
ANOVA, t-tests, regressions, and AID. Such interviews have taken place in states throughout the nation including Georgia, North Carolina, South Carolina, Florida, South Dakota, and Texas.

18. Sheppard v. Maxwell, 384 U.S. 333, 363 (1966); Estes v. Texas, 381 U.S. 532, 542, 543 (1965). See also, Groppi v. Wisconsin, 400 U.S. 505, 509 (1971); Rideau v. Louisiana, 373 U.S. 723 (1963); Irvin v. Dowd, 366 U.S. 717 (1961); Marshall v. United States, 360 U.S. 310 (1959).

19. American Bar association Project on Standards for Criminal Justice, Standards Relating to Fair Trial and Free Press 112 (1968). See also Jurywork, supra note 13, at 21-32; Fighting OPPREsSion in The Courts, supra note 11, at 58; and McConahay, Mullin \& Frederick, The Uses of Social Science in Trials with Political and Racial Overtones: The Trial of Joan Little, 41:1 Law \& Contemp. Prob., Winter 1977, at 205.

20. State v. Willis, 243 Ga. 185, 253 S.E.2d 70 (1979).

21. Lanier County News, March 17,1977 , at 1 .
} 
specialists conducted a two week individual-sequestered voir dire. Extensive juror investigation took place prior to the trial and approximately 500 potential jurors were called. The trial lasted four weeks. The jury quickly pronounced the defendant guilty and the life or death phase commenced. The country's leading death penalty scholars ${ }^{22}$ testified concerning the prejudicial factors related to death as punishment and the ineffectiveness of the death penalty as a crime deterrent. ${ }^{23}$ Religious leaders affirmed the total opposition of their respective denominations to the death penalty. ${ }^{24}$

Jurors were told how Willis was abandoned and left to die at the age of six weeks and how he was miraculously rescued. They were told of psychological tests revealing that he would function well within the prison system and did not constitute a threat to other inmates. ${ }^{25}$ The defendant received the death penalty. The case transcript is six feet high.

Because the public defender system is in its infancy in the South, many execution cases are tried by appointed counsel. Lawyers' fees for these services range from $\$ 150$ in Georgia to $\$ 10,000$ in North Carolina. ${ }^{26}$ Many small town attorneys have discovered that a strong defense in an unpopular case is financial suicide. An attorney in Purvis, Mississippi, faced this problem when he was appointed to a death penalty case. His client was a black man from another state. His wife, active in local politics, threatened to leave him if he actively defended the client. His major commercial client threatened to change attorneys. Furthermore, this attorney had been a prosecutor and maintained many friendships and associations among the prosecutor's staff and the law enforcement staff. The attorney was convinced that his client would get the death penalty. In this case, the murder victim was the only son of a well-known and highly respected highway patrolman. ${ }^{27}$

22. Included: Dr. Hugo Bedau, Dr. Faye Girsh and Dr. Steve Hoenack.

23. The most comprehensive overview of the research in this area may be found in THE Death Penalty in America (H. Bedau ed., rev. ed. 1967), and the sequel to this book, Capital. Punishment in the United States (H. Bedau \& C. Pierce eds. 1976).

24. Dr. Robert Otto and Rev. Eddie Smith.

25. Dr. Brad Fisher, a psychologist who specializes in this field, testified.

26. Gary Hawes received the death penalty in a one-day trial in Georgia. He was fifteen years of age; his two older brothers, also involved in the crime, had been sentenced to life in prison. His appointed attorney received $\$ 150.00$ for his efforts. Hawes v. State, 240 Ga. 327, 240 S.E.2d 833 (1977).

N.C. Gen. STAT. $\$ 7$ A-45 states that at least two experienced attorneys must handle the trial of a death penalty case. They are paid at the rate of $\$ 30.00$ per hour out of court and $\$ 40.00$ per hour in court, as well as receiving funds for reasonable expenses and the services of an investigator. Normally, a low-cost defense for a murder trial using a private attorney costs approximately $\$ 15,000$.

27. State v. Kennedy, Case number 5511 (settled in plea bargaining in the Circuit Court of Lamar County Mississippi 1978). In this case, a special prosecutor had been hired by the family of the victim to insure that Kennedy would receive death as punishment. At the request of Kennedy's appointed attorney, the Team Defense Project assisted in preparations for the trial. On the first day of pre-trial hearings, the courtroom was packed with members of the black community who, at the urging of the Team Defense Project, had come to see that justice was done. 
Intense emotions and prejudices surround such cases. Is it possible under these circumstances for a trial to be untainted by biases? Can the courtroom remain the neutral area envisioned by legal theorists? The answer lies in the jury. It is not inconceivable, even though intense pressures exist outside of the courtroom, that a fair and impartial, twelve-person jury could be selected, even in sensational cases.

As a first step, one must scrutinize the composition of the jury pool. To meet the legal standard, the jury pool must represent a cross section of the community, i.e., there should be a representative proportion of young people, women, blacks and other minorities in the pool. This insures that all groups residing in the community serve as jurors and that jury verdicts reflect the conscience of the community and not just a particular group residing within the community. ${ }^{28}$ Obviously each of these groups hold attitudes and values unique to themselves and as such should have an opportunity to voice these values as members of juries.

It is possible to determine without elaborate surveys whether or not the composition of the pool is adequate. First, select an obvious criterion as the test, for example, the representation of blacks versus whites. Observe, over time, how often the dominant faction represents 100 percent of the entire jury panel. If, for example, whites represent 70 percent of the community population and blacks 30 percent, the chances of seating an all-white jury would be approximately one in one hundred.

Evidence shows that vast areas of this country have seldom selected an all non-white jury in a death penalty case, even though all-white juries frequently serve in such cases. ${ }^{29}$

After looking out into the courtroom, the prosecutor began to talk about taking a plea to life, though prior to this time he had been adamant in refusing to discuss a plea. The blacks sat and waited all day while the plea negotiations went back and forth; by about 6:00 p.m. most of the people had left the courtroom. Almost immediately, the prosecutor announced that all plea negotiations were off and he was going to trial. Members of the Team Defense Project went out to the black community and again urged people to come to the courtroom. They did, filling it once more. Finally, at 1:00 a.m. Victor Kennedy was given a life sentence.

28. See Castaneda v. Partida, 430 U.S. 482 (1977); Taylor v. Louisiana, 419 U.S. 522 (1975); Peters v. Kiff, 407 U.S. 493 (1972) (establishing that a criminal defendant who is not a member of a class excluded from jury service may nonetheless mount a compositional challenge). Alexander v. Louisiana, 405 U.S. 625 (1972); Turner v. Fouche, 396 U.S. 346 (1970); Thiel v. Southern Pacific Co., 328 U.S. 217 (1946). See also Michael, Mullin, O'Reilly \& Rowan, Challenges to he Jury Composition in North Carolina, 7 N.C. CENT. L. REv. 1 (1975); Kairys, Kadane \& Lehoczky, Jury Representativesness: A Mandate for Multiple Source Lists, 65 Cal. L. Rev. 776 (1977); and J. Van Dyke, Selection Procedures (1977).

29. Team Defense Project normally assists in the appeals for hundreds of death penalty cases throughout the nation. An analysis of these cases shows that in the majority of death penalty cases, a minority group member has received the death penalty from an all-white jury. A specific example is Davis v. State, 242 Ga. 901, 252 S.E.2d 443 (1979). Davis received the death penalty from an all-white jury in LaGrange, Ga., a community with a black population of approximately 33 percent. On appeal, the case was remanded for retrial in the sentencing phase on the basis of Witherspoon error. In the second trial, Davis again received the death penalty from an all-white jury. 
Few jurisdictions have representative jury pools. Even fewer consider underrepresentation a problem. Jury commissioners rarely assume the responsibility of matching the proportions of cognizable classes of persons residing in the community with their representation in the jury pool. ${ }^{30}$ The most common sources of juror's names (usually voter and property owner lists) underrepresent young people, women, blacks, Hispanics, Indians and the poor, even though supplementary lists are available. ${ }^{31}$

Jury commissioners in rural areas often "cull" the juror lists themselves. Most states exclude from jury service those who are no longer residents of the county, those who have been convicted of a felony, and those who are physically and mentally incompetent. Minority group representation in the jury pool is small compared to their numbers in the community population. Apparently, these persons are considered unfit to serve as jurors by commissioners who strike them from the list. During the compositional challenge mounted in the murder trial of State $v$. Barrow, ${ }^{32}$ one jury commissioner, asked his reasons for excusing so many blacks from the jury pool, responded: "Well, you just can't put the mules in with the horses, can you?"33

It is not unusual for execution cases to begin with a significant underrepresentation in the jury pool of those who are more likely to be defenseoriented, i.e., young people, women, minority group members, and the poor. Assuming that underrepresentation is the case and that the exclusion of such groups has rendered the jury pool more prosecution prone than would be expected if a cross section of the community were represented, the question is: does the subsequent juror selection further limit the probability of a fair and impartial jury?

Voir dire optimally results in the most prejudiced jurors being dismissed from juror service by either the court or the lawyers. During voir dire, the prosecution and the defense may prove to the court that a potential juror cannot follow the law and should be struck for cause. In such cases, the juror will be excused at the court's discretion. There is no limit to the number of prospective jurors who may be excused in this manner. The difficulty lies in the ability to convince the court that a person's attitudes are such that he will

30. See, e.g., Castaneda v. Partida, 430 U.S. 482 (1977); Taylor v. Louisiana, 419 U.S. 522 (1975); Alexander v. Louisiana, 404 U.S. 625 (1972); Turner v. Fouche, 396 U.S. 346 (1970); Carmical v. Craven 457 F.2d 582 (9th Cir. 1971); United States v. Zirpolo, 450 F.2d 424 (3rd Cir. 1971); Salary v. Wilson, 415 F.2d 467, 472 (5th Cir. 1969) ("[g]ood faith, or lack of an improper motive, is not a defense to the failure of jury board members to discharge the affirmative constitutional duties cast upon them").

31. This fact is well-established in research concerning voter participation. W. Flanigan \& N. Zingale, Political Behavior of the American Electorate 9 (1975). "Two federal district courts and several state jurisdictions now use multiple lists," JuRYwork, supra note 13, at 46.

32. Barrow v. State, 235 Ga. 635, 221 S.E.2d 416 (1975).

33. Barrow v. State, pretrial transcript, at 158 . 
be unable to follow the law and, consequently, be fair. Few prospective jurors are excused from service in this manner. ${ }^{34}$

Additionally, the prosecution and the defense have a set number of peremptory strikes that may be used at any time. The number of peremptory strikes allowed to each side varies from state to state. Generally, the defense may exercise at least an equal number of peremptory strikes as the prosecution; sometimes the defense has more strikes than the prosecution. ${ }^{35}$

Due to the highly prejudicial atmosphere in execution cases, probative and sifting voir dire is a basic requirement. The more an attorney is able to explore a juror's attitudes in regard to the issues in a particular case, the more likely it is that fair and impartial jurors will be selected. ${ }^{36}$ An individualsequestered voir dire provides the best forum for determining people's deeply-held attitudes and the level at which their decisions as jurors will be made. Frequently, however, the voir dire is conducted with the entire group in the courtroom responding to questions by raising their hands. People in such situations are reluctant to reveal their true feelings, especially when an execution case is being tried.

During the juror selection process, both the prosecutor and the defense attorneys vie for jurors who lean toward their particular side. Optimally, the judge assumes an impartial role in this process; however, judges are often former prosecutors and tend to side with the prosecution when rendering decisions concerning a juror's ability to serve fairly and impartially. ${ }^{\mathbf{3 7}}$

In execution cases, prosecutors generally use all of their peremptory challenges to remove blacks from the jury. ${ }^{38}$ All trial lawyers, be they prosecution or defense, know from experience that black persons are less likely to convict

34. In a post-trial interview conducted in the summer of 1979 by Kimellen Tunkle of the Team Defense Project, Lucille Waddell, a trial juror in the Wayne Coleman death penalty case, said that she felt it was her duty as a friend of the Aldays (the family members who were murdered) to serve on the jury. She said that she had felt that the Alday family needed justice. Additionally, she said that the defendants should have been hung from a scaffold in a bathing suit. At the time of the trial Waddell had affirmed under oath, and Judge Walter I. Geer had held, that she was capable of being fair. Of some interest is the fact that Peter Zack Geer, special prosecutor employed in this case, was the nephew of the judge and a former Lieutenant Governor of the state of Georgia.

35. J. VAN DYKE, supra note 28 , at 282-83. All federal courts and twenty state courts allow more peremptories to the defendant.

36. See H.P. Fahringer, In the Valley of the Blind: A Primer on Jury Selection in a Criminal Case, 43:4 Law Contemp. Prob., Autumn 1980, at 116.

37. Judge Robert A. Collier, Jr., in addressing the North Carolina Academy of Trial Lawyers in Greensboro on July 23, 1977, stated that he felt it was time that the marriage between prosecutors and judges in the state of North Carolina come to an end.

38. This practice has been successfully challenged in People v. Wheeler, 22 Cal.3d 258, 583 P.2d 748, 148 Cal. Rptr. 890 (1978). For the first time, a court has limited the purposes for which a party may exercise a peremptory challenge, in particular against those groups who are members of a "cognizable class" of persons and when there is a "strong likelihood" they are being challenged because of their group association rather than because of any "specific bias." Id. at 280, 583 P.2d at 764, 148 Cal. Rptr. at 905. 
than white persons. Survey data uphold this hypothesis. Data, from more than 150 telephone and face-to-face interviews conducted by the author throughout the South, support the notion that blacks are less likely to be punitive than whites. Significant differences in the attitudes held by survey respondents are also much more likely to break down along racial lines than along other demographic characteristics such as sex or age. ${ }^{39}$

This effect is especially apparent in the voir dire process when the questions concern belief in the death penalty. On a number of occasions, the author has observed voir dires in which every black person who was questioned opposed the death penalty while every white person supported it. Of course, belief in the death penalty varies in degree. Some persons believe that the death penalty is the appropriate punishment for any case in which first degree murder has been the jury's verdict. Others feel that it is appropriate in only a few situations.

Since blacks frequently oppose the death penalty, prosecutors not only strike them peremptorily, but seek to have the court excuse them for cause. In the Witherspoon decision, the Supreme Court clearly stated that potential jurors who expressed the feeling that they could never, under any circumstances, consider inflicting the death penalty may be excused from service by the court. ${ }^{40}$ Because of their opposition to the death penalty, large numbers of blacks are struck for cause during any death penalty case. ${ }^{41}$

Many defense attorneys have moved the court to allow jurors who are opposed to the death penalty to serve in the first (guilt or innocence) portion of the trial. Should a verdict of guilty be returned, these jurors could then be excused and replaced by individuals who did not oppose the death penalty. Other suitable options would be to proceed with a jury comprised of fewer than twelve persons or to select an entirely new panel. As yet, no court has allowed this motion. This is disheartening in view of the fact that a number of concurring American studies have shown that "death qualified" juries are

39. Shortly after the execution of Gary Gilmore in 1977, Dr. John H. Curtis and K.B. Perkins of Valdosta State College, Valdosta, Georgia administered a structured questionnaire to 808 South Georgians to determine whether selected background variables predicted attitudes toward capital punishment. They found significant relationships existed for race: the majority of whites were in favor of capital punishment while blacks were largely opposed to it. Persons over the age of fifty-five were found to be significantly in favor of capital punishment, as were persons with incomes greater than $\$ 20,000$ per year. Males generally favored capital punishment, as did subjects with an undergraduate level education or less. In addition, those most opposed to capital punishment were often those who reported themselves as non-members of major religious denominations. Marital status was the least effective variable analyzed. The analysis of data included examination of contingency tables, Pearson's correlation coefficients, t-tests, and regressions. The unpublished paper entitled The Capital Punishment Controversy: South Georgian Attitudes, was funded in part by a grant in the Division of Graduate Studies, Valdosta State College.

40. Witherspoon v. Illinois, 391 U.S. 510, 522-23 n.21 (1968).

41. In the trial of Henry Willis, every black person on voir dire declared some opposition to the death penalty. Of the thirty-two black individuals who expressed strong opposition to the death penalty, sixteen were struck for cause by Judge John Langford. 
more punitive than are non-death qualified juries. Not only are such juries more punitive, but when presented with the same fact situation, they are significantly more likely to find the defendant guilty than are non-death qualified juries. ${ }^{42}$

A defendant on trial in a death case is faced with this situation: he is denied the opportunity to select jurors who represent a cross section of the community; of the jurors available to him, he may select only death qualified jurors for service in both the guilt or innocence portion of the trial as well as in the second, sentencing portion; he can expect, moreover, that the few black jurors who have survived the prejudicial sifting out process will be struck peremptorily by the prosecutor.

Fortunately, appellate courts have begun recently to address the problem of prosecutors using all of their peremptories on black persons. In People $v$. Wheeler, ${ }^{43}$ the California Supreme Court held the use of prosecutorial strikes against black persons to be error. The court reasoned that actual intentional discrimination need not be shown; a showing that a cognizable class of persons was systematically excluded from juror service was sufficient. ${ }^{44}$

Though the Witherspoon opinion permits the states to exclude jurors who are conscientiously opposed to the death penalty, ${ }^{45}$ the Supreme Court has yet to hold that persons who would automatically vote for the death penalty in the second trial when they found the accused guilty of first degree murder in the first trial may also be excluded. In upholding the bifurcated or twotrial system presently employed throughout the United States, ${ }^{46}$ in Gregg $v$. Georgia the Court indirectly held that a person should receive the death penalty only when a cross section of the community in which the crime occurred felt that the death penalty was the appropriate punishment. State statutes automatically imposing the death penalty were found unconstitutional. ${ }^{47}$ However, trial judges in many death penalty cases do not excuse for cause jurors who would automatically vote for the death penalty. The law, as the old saying goes, is in the jaw of the judge.

As a result of limited source lists, improper culling of the lists by jury commissioners, the death qualification of jurors, and prosecutorial strikes; it is not

42. Included in this research are: Bronson, On the Conviction Proneness and Representativeness of the Death Qualified Jury: An Empirical Study of Colorado Veniremen, 42 U. CoLo. L. Rev. 1 (1970); Goldberg [Girsh], Toward Expansion of Witherspoon: Capital Scruples, Jury Bias, and Use of Psychological Data to Raise Presumptions in the Law, 5 Harv. C.R. C.L.L. Rev. 53 (1970); Jurow, New Data on the Effect of a "Death-Qualified" Jury on the Guilt Determination Process, 84 Harv. L. Rev. 567 (197I); and H. Zeisel, Some Data on Juror Attitudes Toward Capital Punishment (1960).

43. People v. Wheeler, 22 Cal.3d 258, 583 P.2d 748, 148 Cal. Rptr. 890 (1978).

44. Id. at $280-8 \mathrm{I}, 583 \mathrm{P} .2 \mathrm{~d}$ at $764,148 \mathrm{Cal}$. Rptr, at 903.

45. 391 U.S. at $522-23$ n.21.

46. Gregg v. Georgia. 428 U.S. 153 (1976).

47. Woodson v. North Carolina, 428 U.S. 280 (1976); Roberts v. Louisiana, 428 U.S. 325 (1976). 
uncommon to have an all-white jury deciding whether a black defendant accused of murdering a white person should live or die. This type of discrimination may be found in communities with a black population of 30 percent or more. In such instances, the probability of a death sentence is heightened, no matter what the evidence.

It is conceivable that, even though the defense must select jurors who are primarily white and are death qualified, a fair and impartial jury could be selected. The voir dire can be an effective tool in revealing any preconceived prejudices and opinions that might be held by potential jurors.

One important area of the voir dire concerns the publicity generated by the case, which may have resulted in potential jurors having formed an opinion concerning the guilt of the accused. As stated above, murder cases often generate extensive publicity and are primary topics of discussion among the residents of the community. Often, during the voir dire, potential jurors state that they have read about the case, have discussed it with their family and friends at some length, and as a result have reached an opinion as to the guilt of the accused. Normally, judges intervene at this point and ask the jurors whether they can lay aside their opinions, listen to the evidence presented in court, do their duties as jurors, and render a decision fairly and impartially based only on what they have heard in the court. In response to this question, most jurors straighten their bodies, look the judge straight in the eye and respond, "Yes, sir!"

A murder trial held in Colquitt, Georgia concerned the systematic murder of six family members who had been greatly loved by friends and neighbors in the small town of approximately 2,000 . Although the publicity had been intense throughout Gerogia and especially in the Colquitt area, the trial judge denied a change of venue in the case. The judge also did not allow challenges for cause to excuse persons who had been friends of the victims. As a result, a majority of the twelve jurors had been friends of the victims and a few had attended the funeral. Though these problems have been strongly raised by the defense upon appeal, as yet no appellate court has found that the trial judge erred either by actually seating the friends of the victims or by not having moved the location of the trial. Predictably, all three defendants received the death penalty. ${ }^{48}$

Though the necessity of a change of venue in order to secure fair and impartial jurors is open to interpretation by the various parties, theoretically, all jurors, no matter what the trial location, should be able to presume the accused innocent of all charges against him. As a practical matter, however, jurors often assume that the accused must be guilty of something, otherwise the

48. Coleman v. State, 237 Ga. 84, 226 S.E.2d 911 (1976). But see J.M. Hassett, A Jury's Pre-trial Knowledge in Historical Perspective: The Distinction Between Pre-trial Information and "Prejudicial" Publicity, 43:4 LAw \& Contemp. Prob., Autumn 1980, at 155. 
person would not be on trial. It does not make good sense to assume that a person is innocent after an investigation has occurred, an arrest made, a decision made by the prosecution to take the case to the grand jury, and a true bill issued by the grand jury indicting this person for murder. ${ }^{49}$

Amazingly, 37 percent of respondents to a national survey concerning the public image of the courts believed that a defendant should prove his innocence. ${ }^{50}$ This means that we can expect in any court in the nation and for any trial, that four out of ten potential jurors do not believe that the defendant is innocent of the charges against him.

Jurors assume that in order to reach a decision, they must hear from both sides. It is difficult to make clear to jurors that they must compare a totally innocent person with the weight of the facts presented against him by the prosecution. Further, they must understand that even though the evidence may cause them to think that the defendant is guilty, they must not vote guilty until they are convinced beyond a reasonable doubt. Few jurors ever really understand the important distinction between innocence and voting not guilty.

Many courts disallow probing voir dire into a potential juror's understanding of legal presumptions. ${ }^{51}$ In these courts, jurors may be asked only whether they will follow the law as the judge will charge them. They may not be asked what the presumption of innocence means to them. Though at the outset many jurors do not understand the legal presumptions, many come to a clear appreciation of their duties if an intensive educational voir dire is allowed. If voir dire is curtailed in this area, it severely limits the defense's ability to have jurors removed for cause.

Other judges make the assumption that legal theory is too difficult for the jurors to understand and limit exploration in these areas. In North Carolina $v$. James Powell, ${ }^{52}$ a death penalty case, Judge Marsh McLelland stated in open court that he considered the presumption of innocence to be only a legal nicety. Further defense efforts to conduct voir dire in this area were denied..$^{53}$

49. According to my survey research, prior to the actual trial it is common for more than 30 percent of respondents to believe a defendant is guilty without having heard any evidence whatsoever. It is not uncommon to find 9 or 10 percent of respondents who believe the defendant is guilty even though they profess to be totally unaware of the case itself. In-depth post trial interviews with jurors have confirmed this finding.

50. Coleman v. State, $237 \mathrm{Ga} .84,226$ S.E.2d 911 (1976). Yankelovich, Skelley \& White, The Public Image of the Courts: A National Survey of the General Public, Judges, Lawyers, and Community Leaders (prepared for the National Center for State Courts, March 1978).

51. This varies from state to state and court to court. Generally the breadth and scope of the voir dire is discretionary with the judge. In Georgia, case law has upheld the prevailing attitude of judges who allow no voir dire into a potential juror's understanding of the law, Holloway $v$. State, 137 Ga. App. 124, 222 S.E.2d 898 (1975). As noted later in the article, two North Carolina Superior Court judges who preside in the same judicial district differ greatly in the type of voir dire that they allow in their courtrooms.

52. State v. James Alonzo Powell, 78 CRS 209972103521037 , Council of N.C. State Bar, 294 N.C. $750(1978)$.

53. Judge McLelland's remarks, made in open court, were noted by the author. 
Often a probing voir dire is not allowed due to the length of time that it will consume. Judges exert a tremendous amount of pressure on attorneys to move their cases along, especially criminal cases. Judges' attitudes about the time required to litigate civil cases are markedly different. For example, the IBM antitrust suit has been in court ten years.

The pervasiveness of potential jurors' assumptions that the accused is guilty was revealed in the armed robbery/murder trial of North Carolina $v$. Washington ${ }^{54}$. Attorney Jerry Paul was allowed an extensive voir dire by Judge Coy Brewer and was able to render all potential jurors ineligible by showing that they were unable to follow the law as required by the court. He exposed three areas of prejudice:

(1) some jurors expected to hear evidence from the defense;

(2) they would be unable to presume innocence on one charge if they found Washington guilty on another charge; and

(3) they were unable at the outset of the second trial to presume that Washington should receive a life sentence if they had found him guilty of first degree murder in the first trial.

Juror selection lasted six weeks. After four weeks, Judge Brewer acknowledged that Paul could remove any juror he chose for cause and suggested that, in the interests of time, no more peremptories need be used by either side. Thereafter, any juror found unacceptable by either side was immediately excused by the court.

Paul is extremely skillful at eliciting honest and thoughtful responses from potential jurors, but the voir dire conducted by many attorneys elicits shallow and meaningless, socially acceptable responses. Having received no training in understanding human behavior, many lawyers are unaware of basic techniques such as the use of open-ended questions in establishing rapport with people. Often they select jurors by resorting to stereotyping. Reportedly, even Clarence Darrow claimed that he always selected alcoholics and never selected barbers.

Since racial prejudice is acknowledged as potentially prejudicial in a trial, courts normally allow voir dire in this area. ${ }^{55} \mathrm{~A}$ showing of racial prejudice on the part of a juror results in his or her excusal for cause by the judge. The standard question asked of jurors to determine their racial prejudice is: "Now, Mr. Jones, as you can see, the defendant on trial here is a black man. The victim in this case was a white man. Do you think that this fact will affect your ability to be fair in this case?" During the voir dire of thousands of persons, the author has yet to witness one who responded that this might affect him. ${ }^{56}$

54. State v. Robert E. Washington, 77 CRS 49567.

55. Ham v. South Carolina, 409 U.S. 524 (1973).

56. The author has witnessed both state and federal jury selections in such states as North 
The ability to have jurors removed for cause constitutes a major tool of the defense in reducing the odds against prejudiced jurors. As stated above, most states allow an equal number of peremptory strikes to the prosecution and the defense. A few allow more strikes to the defense, and a very few allow double the number of strikes to the defense as to the prosecution. ${ }^{57}$

The number of strikes allowed the defendant is insufficient when one considers that 37 percent of jurors presume the defendant guilty in any case. ${ }^{58}$ In the exacerbated situation faced by persons on trial for their lives, a conservative estimate of the percentage of persons assuming that the accused is guilty is 50 percent. The greater the amount of publicity, the more heinous the crime, the smaller and more rural the community, the more southern the trial location, the greater is the potential that jurors have already concluded that the accused is guilty.

Unfortunately, few defense attorneys appreciate the effectiveness of developing their ability to challenge potential jurors for cause. Few defense attorneys appreciate the depth and breadth of unfairness faced in the trial of execution cases. Not only do they not understand this prejudice, but they are unable to educate judges (who probably understand the defense problems even less) as to the magnitude of the problems they face. As a result, judges usually do not permit the type of voir dire that would facilitate the exposure of prejudicial attitudes held by potential jurors.

Furthermore, even if the judge allowed an extensive voir dire, most attorneys demonstrate a lack of skill in asking questions which elicit meaningful information from potential jurors. Many lawyers ask questions of potential jurors in the same way they would cross examine a hostile witness. It appears very difficult for lawyers to establish the kind of rapport that is necessary for the jurors to open up and reveal their beliefs and values.

Without question, the actual evidence presented in the courtroom constitutes one of the least important factors in a juror's determination of whether the defendant should live or die. In more than one instance, persons condemned to die were later found to be innocent of all charges against them. ${ }^{59}$

Carolina, South Carolina, Florida, Georgia, New York, Oklahoma, Texas, South Dakota, and Pennsylvania.

57. J. VAN DYke, supra note 28. If one assumes that the survey data reported by the National Center for State Courts is correct and that in fact some 37 percent of those interviewed feel that a defendant is probably guilty in any case, then one may conservatively assume that in an execution case the percentage of biased jurors rises to 50 percent or more.

58. Given human fallibility in jury selection even when the defendant is allowed twice as many strikes as the prosecutor, the strike situation is insufficient to protect the rights of the defendant to a fair and impartial jury. Yankelovich, Skelley \& White, supra note 50.

59. Wilbert Pitts and Freddie Lee, imprisoned in Florida for twelve years, were freed in 1975 after the actual killer confessed to the crime.

Ironically, Purvis, Mississippi. the trial location for Victor Kennedy, was named for Willie Purvis who was wrongfully sentenced to death for a crime he did not commit. George Brandon was sentenced to die for a murder in New Jersey in 1918, though the real murderer later confessed. Brandon's lawyer was disbarred for mishandling the defense. Brandon was exe- 
In his opinion in the Furman case, Justice Thurgood Marshall questioned whether people had actually considered the societal implications of imposing the death penalty on their own citizens. ${ }^{60}$ In today's world of rapidly rising crime rates, the probability of people questioning their belief in the death penalty seems even less likely. Perhaps the rapidity of change in our society has caused Americans to press for more stringent punishment in the courts, in particular a demand for reinstitution of the death penalty. More and more jurors indicate their belief in the death penalty. The Supreme Court has justified the legalization of the death penalty on the ground that the public desires it. ${ }^{61}$ Three persons have been executed since 1976 and many others may soon follow. ${ }^{62}$

Regardless of one's emotional, moral, or pragmatic beliefs concerning the validity of the death penalty, it is clear that the traditional legal safeguards insuring a defendant the right to a fair trial are violated in execution cases. Coupled with the high degree of emotionality and prejudice that usually surrounds such cases is the highly prejudicial practice of excluding from jury service those persons morally opposed to the death penalty while retaining those in favor of it.

Oberer stated the effects of this practice some eighteen years ago:

The consequence is that a jury qualified on the death penalty will necessarily have been culled of the most humane of its prospective members . . . And when it is further considered that the issue of guilt or innocence in less important cases-the non-capital cases-is determined by a jury not similarly shorn of its most humanely disposed constituents, the result becomes even more ironic: the graver the charge, the less the protection accorded the accused.$^{63}$

cuted. Frank Smith was killed in Connecticut in 1949, the state discovering its error only minutes after the execution.

60. Furman v. Georgia, 408 U.S. 238, 360-69 (Marshall, J., concurring) (1972).

61. The Court's reasoning appears on page 860 of the decision. Prior to Gary Gilmore's execution at the Point of the Mountain Prison in Utah in January 1977, there had been no legal executions in the United States since 1967. Though Gilmore was clearly suicidal, John Spenkelink resisted his death with all of the forces at his command until he was finally executed in May 1979 , at Stark Prison in Florida. Jesse Bishop was executed in Nevada on October 22, 1979. The relationship between capital punishment, suicide and murder is discussed by psychiatrist George Solomon in People WeEkLy, January 17, 1977, at 48-51.

62. There are 642 people on death row. The only potentially imminent execution is that of Jack H. Potts on June 5, 1980. 241 Ga. 67, 243 S.E.2d 510 (1978). Numerous appeals can arise when the death penalty is invoked. Although there is a limit to the number of appeals the courts will hear, a stay can generally be obtained pending the initial round of appeals. This round includes appeals to the appropriate federal district court, the circuit court of appeals, the U.S. Supreme Court, and the appropriate state supreme court. Potts has expressed the desire to forego available appeals.

U.S. Supreme Court decisions on the constitutionality of a given statute may also effect a wide range of cases. If a particular sentencing statute is found unconstitutional, similar statutes of other jurisdictions may be called into question. Consequently, relief may be mandated for any prisoner condemned under the stricken statute or like statutes of other jurisdictions. Interview with Alan McGregor, spokesman for the Southern Death Penalty Information Center, Durham, N.C. (May 20, 1980).

63. Oberer, Does Disqualification of Jurors for Scruples Against Capital Punishment Constitute Denial of Fair Trial on Issue of Guilt?. 39 Texas L. Rev. 545, 549 (1961). 
Execution cases are different from other cases and they should be treated with that in mind. They serve as symbolic indicators of our feelings about the poor and minorities, and of our true commitment to justice and equality. Presently, the indicators are not favorable. 